\title{
Game-Based Badminton Smash Training Model for Beginner
}

\author{
Asrori Yudhaprawira ${ }^{1,2 *}$ Moch. Asmawi ${ }^{1}$ Firmansyah Dlis $^{1}$ \\ ${ }^{1}$ Postgraduate Physical Education, Universitas Negeri Jakarta \\ ${ }^{2}$ Faculty of Education, Universitas Bhayangkara Jakarta Raya \\ *Corresponding author. Email: asroriyudhaprawira_7217140055@mhs.unj.ac.id
}

\begin{abstract}
This research aimed to produce a game-based badminton smash training model for beginners (novice players). The research used the research and development (R\&D) methods of Borg and Gall. The research subjects were 30 novice players in PB. Jaya Raya Jakarta. Data collection techniques were carried out by observation, documentation, interviews, and tests. Data analysis was carried out qualitatively and quantitatively. The model development was done through limited trials, extensive trials, and effectiveness tests. The results of the research were: (1) The game-based badminton smash training model can improve the accuracy of novice players; and (2) The game-based badminton smash training model was more effective and efficient in increasing achievement, interest, and motivation for novice players in training.
\end{abstract}

Keywords: training, model, smash, game

\section{INTRODUCTION}

Nowadays, interest in sports activities are not only for individuals or small groups of people, but it becomes an integral part of national development as an effective means for increasing human resources and has economic and political impacts that will bring social and lifestyle changes. The development of achievement sports both organized by the nation and the private sectors was an illustration of concern and support in advancing national sports achievements in order to compete at the national level. Guidance on achievement sports organized by the state and the private sector is an illustration of caring and supporting advancing sports achievements [1]. One of the sports that is able to compete at the international level is badminton, although it currently does not dominate the world's badminton achievements. This is happened due to the development and progress of Science and Technology (IPTEK), even now Indonesian women's badminton achievements are lagging behind.

Badminton is an easy game to play considering the light racket and the ball running straight and regularly without turning [2]. Therefore, a badminton player who wants to become an accomplished player must learn and master the techniques and tactics as well as possible. Badminton is a game that can be played by one person against one person or two people against two people.
Basic technique is the main thing that must be mastered and understood by every player in playing badminton" [3]. A badminton player needs to master and understand the basic components and basic techniques of playing badminton. Basic technique is the main thing that must be mastered and understood by every player in playing badminton. The basic techniques of hitting in badminton include: serve, underhand, lob, dropshot, smash, neting, and drive [4].

Badminton can become a culture and belong to the nation as well as become an example for other sports in Indonesia. Badminton is also one of the popular sports for people; the number of badminton clubs scattered throughout the nation indicates that badminton is very popular. The government and private support in the development of badminton is very large. It is also supported by school and college curriculum programs and there are many badminton clubs that are developing in the hope for achievement regeneration [5]. The main factor in improving badminton achievement is "the coaches and the players" because the abilities of coaches and players cannot be separated like two sides of a coin that have value in the achievement process. Talented and highly motivated players help in the achievement process. The tasks and roles of coaches are very complex too because they must always be able to adapt to the latest developments and always have innovation and be 
creative in doing trainings. They also demanded accomplishment challenges. The basic bio motoric components in every sport, especially badminton, are strength, endurance, speed, flexibility, and coordination. The basic bio motoric components in badminton are the main strength, endurance, speed, flexibility and coordination [6]. These physical condition components need to be trained so achievement can be accomplished or improved. Physical conditioning trainings play important role in maintaining and improving physical performance abilities.

In addition to the physical aspect, the basic techniques in badminton are a vital factor for achieving accomplishment in sport. Individual basic skills are very important to the success of achievement. There are some basic skills in badminton, which are basic techniques for overhead stroke and the underhand stroke. Badminton has complex and dynamic movement characteristics. To be able to do the movement, a player requires good skills and coordination when hitting the shuttlecock and its placement. Badminton belongs to sports group games. The badminton game can be played indoor or outdoor, with the field being delimited by lines in a certain length and width. Badminton has complex and dynamic movement characteristics, to do so requires skill and good coordination skills when hitting the shuttlecock and its placement [7].

Some of these basic techniques are very vital to get achievements in badminton. However, the basic technique that is able to score points is the smash. Smash is the most important skill in badminton. Other basic skills are indeed supportive in playing badminton but to win the game and score achievements, smash is definitely needed. The basic technique that is able to score points is smash, this is the most important skill in badminton [8]. Other basic skills do support the game and score a victory".

On the other hand, the reality is inversely proportional to the players' skills on the field. From the observation to several sports clubs in region, it is shown that basic smash technique training only focuses on improving the smash techniques, without paying attention to the physical conditions supporting the smash techniques. In addition, the trainings carried out were only based on the coaches' memories about what he did when they were players (athletes). It was worsen as the trainings were done without any training program. This certainly had bad impacts on the badminton players' ability to develop their skills. It meant the reality showed that the basic technique skills of badminton players in doing smash were mediocre. It can be said that the basic technique practice of badminton smash had not been programmed properly and did not use good and varied training methods and also did not pay attention to the physical components that support badminton smash skills. Therefore, the badminton players' skills to do smash were still poor. The pattern of attacking mostly did not use smash. It indicated that the badminton smash training model had not been programmed properly.

\section{METHOD}

The purpose of this research was to train smash skills in badminton with the targets were PB Jaya Raya Jakarta beginner players. The Research and Development method from Borg and Gall was used, with time details as follows: (a) Needs analysis; (b) Planning model development; (c) Designing training development model; (d) Expert validation and model revision; (e) Small group trial and revision; (f) Field trial and revision. Planning and preparation were made in order to provide clear instructions and guidance in the implementation of research later in the training. Planning and preparation of training models were factors that determine the success of a program. In connection with that, the game-based smash training model program which compiled and developed was in the form of modification and creativity in badminton training.

\section{RESULTS}

Based on the data collected, there were several program designs that need to be revised before conducting small and large group trials. Product revision is intended to make the developed program design more perfect.

After conducting a small group trial and revising the product development, the field trial was done and was revised. Therefore, to find the effectiveness of the program, it is necessary to do t-test. Before analyzing the data, it is necessary to test the normality of the pre-test and post-test results of game-based badminton smash training model using the Liliefors test $(\alpha=0.05)$. A summary of the normality test calculation results is shown in the table below:

Table 1. Test of normality

\begin{tabular}{|l|l|l|l|l|}
\hline Group & $\mathrm{N}$ & Lcount & Ltable & Evidence \\
\hline 1 & 30 & 0,052 & 0,114 & Normal \\
\hline 2 & 30 & 0,011 & 0,114 & Normal \\
\hline
\end{tabular}

The result of normality test was shown in table 1: the value of Lcount obtained from pre-test and post-test data was smaller than Ltable at the real level $=0.05$. Thus, it can be concluded that all pre-test and post-test data were normally distributed.

Before conducting further data analysis, it was necessary to test the effectiveness of the program by using t-test with SPSS ver. 25 , it can be seen in the table 2 . 
Table 2. Test of effectiveness

\begin{tabular}{|c|c|c|c|c|}
\hline \multicolumn{2}{|c|}{} & $\mathrm{t}$ & $\mathrm{df}$ & Sig.(2-tailed) \\
\hline Pair & $\begin{array}{c}\text { Pre-test } \\
- \text { Post- } \\
\text { test }\end{array}$ & 21,974 & 29 & .000 \\
\hline
\end{tabular}

Based on the output table above, it can be seen that the results of t-count $=21.974, \mathrm{df}=29$, and $\mathrm{p}$-value 0.000 $<0.05$. It can be concluded that there was a significant difference in the results of pretest and posttest data. Thus, it can be stated that the game-based badminton smash training model for beginners was effectively used to improve badminton smash skills on the players.

\section{DISCUSSION}

From the results of the needs analysis and the findings, it can be seen that the training process generally ran according to the program. Nevertheless, the researchers still saw many shortcomings, especially during training due to the lack of enthusiasm of participants in the beginner category. The student athletes felt bored with the training model given by the coach because the program was less creative in providing badminton smash material. This reinforced the importance of developing a game-based badminton smash training model for beginners.

The game-based badminton smash training model will be maximally success if the player hit hard and straight to the diagonal area. In badminton game, unexpectedly half smash stroke at the right time is often more successful in beating the opponent. In general, this stroke is fast and hard because it uses a lot of energy, it will drain the energy that makes the player's standing position unsteady [9]. The stroke has full power, but usually the shuttlecock is less directed. This smash should be done along the line or fully aimed at the opponent's body. What needs to be considered is the player's position. It must be changed: from a forward facing position to the right or attack to the right, so making a cut stroke will be easier and profitable.

The smash in badminton is one of the strokes that often result in direct score. This blow requires both fast and sudden hand swing motion and also produces a hard stroke that drops the shuttlecock steeply [10]. The power used in doing smash is very large, so careful calculation is needed to make this stroke.

From the results it can be seen that the game-based badminton smash training model was effectively used if the smash was done using slice racket. According to Poole, the shuttlecock should be stroke down with greatest fall possible angle. This fall angle is more important than the speed of the shuttlecock, so the player must try to stroke it at the maximum height [11].

\section{CONCLUSION}

After analyzing and discussing the data, it can be concluded that the hypothesis was proven where the game-based badminton smash training model for beginners was able to help coaches and athletes to improve smash skills effectively and efficiently. Therefore, the use of game-based badminton smash training is effective to be used.

\section{AUTHORS' CONTRIBUTIONS}

AY: design, writing, data analysis, data collection; MA: data analysis, writing, FD: writing.

\section{ACKNOWLEDGMENTS}

The authors thank to all participants who involved and all parties that support this study.

\section{REFERENCES}

[1] Joo, C. H. (2018). The Effects of Short Term Detraining and Retraining on Physical Fitness in Elite Soccer Players. PLoS ONE, 13(5), 1-15. https://doi.org/10.1371/journal.pone.0196212

[2] French, K. E., Werner, P. H., Rink, J. E., Taylor, K., \& Hussey, K. (1996). The Effects of a 6-Week Unit of Tactical, Skill, or Combined Tactical and Skill Instruction on Badminton Performance of NinthGrade Students. Journal of Teaching in Physical Education, 15(4), 418-438. https://doi.org/10.1123/jtpe.15.4.439

[3] Sulistiyono. (2017). Development and Validation of Kid Tsu Chu Futbol Games for Character Development. Journal of Physical Education Health and Sport, 4(1), 29-34. https://doi.org/10.15294/jpehs.v4i1.8222

[4] Zutshi, K. (2019). Pace and variability in the badminton jump smash and the tennis serve. Journal Sport Science, 4(3), 97-108.

[5] Nagasawa, M., Hatori, Y., Kakuta, M., Hayashi, T., \& Sekine, Y. (2012). Smash Motion Analysis for Badminton from Image. Proceedings of the IEEJ Image Electronics and Visual Computing Workshop, 1-8.

[6] Wahyudi, M., Hartono, M., \& Rifai RC, A. (2018). Technical Skill Analysis of Badminton Blow on Teenager Players of Pendowo Club Semarang. Journal of Physical Education and Sports, 7(2), 119 123. Retrieved from https://journal.unnes.ac.id/sju/index.php/jpes/articl e/view/24166 
[7] Sutarjo, A. N. (2018). Pengaruh active isolated stretching terhadap peningkatan jump smash pada pemain bulutangkis di muhammadiyah badminton club. Jurnal Olahraga Indonesia, 3(4), 78-86.

[8] Digy, E. X., Dnhuvàhog, D., \& Thomas, D. Q. G. (2020). Changes in Badminton Game Play across Developmental Skill Levels among High School Students. Journal of Physical Education and Sport, 7(1), 29-37.

[9] Gazali, N., \& Cendra, R. (2019). Badminton Service Construction Test in Universitas Islam Riau Penjaskesrek Students. Journal of Physical Education, Health and Sport Shor, 6(1), 1-5.

[10] Zuhri, F. N. (2019). Ketepatan Jumping Smash Bulutangkis Studi Pada Peserta Ekstrakurikuler Bulutangkis Di Smp Negeri 2 Sidoarjo. Jurnal Juara Olahraga, 3(4), 99-103.

[11] Wang, J., \& Liu, W. (2012). Changes in Badminton Game Play across Developmental Skill Levels among High School Students. ICHPER-SD Journal of Research, 7(2), 29-37. 